\title{
Smoked African Catfish (Clarias gariepinus) Sampled from Two Markets and Occurrence of Microbes
}

\author{
J. A. Daramola, C. T. Kester, and O.O. Allo
}

\begin{abstract}
The study was carried out to assess some microbiological qualities of smoked African catfish, Clarias gariepinus retailed in Sango and Ota markets in Ogun state, Nigeria. Six smoked fish retailers were randomly selected from the markets and 36 fish samples were collected. The samples of smoked catfish were assessed weekly for a period of six weeks for microbiological parameters such as Total plate count (TPC), Total coliforms count (TCC), Staphylococcus count and mould count. In this study, the microbial load of the smoked Clarias gariepinus samples retailed in the two study sites increased weekly during the period of storage. TPC increased from $4.75 \pm 0.014 \log 10 \mathrm{CFU} / \mathrm{g}$ for smoked samples from Ota market, retailer 1 (OMR1) in week 0 to $5.11 \pm 0.021 \log 10 \mathrm{CFU} / \mathrm{g}$ for samples from Ota market, retailer 3 (OMR3) in week 5. TCC ranged from $1.47 \pm 0.001 \log 10 \mathrm{CFU} / \mathrm{g}$ to $2.43 \pm 0.049 \log 10$ CFU/g; Staphylococcus from $2.15 \pm 0.070 \log 10(\mathrm{CFU} / \mathrm{g})$ to $2.66 \pm 0.014 \log 10(\mathrm{CFU} / \mathrm{g})$ and $1.82 \pm 0.070 \log 10 \mathrm{CFU} / \mathrm{g}$ to $2.92 \pm 0.071 \log 10 \mathrm{CFU} / \mathrm{g}$ for mould counts. The smoked Clarias gariepinus from the markets could not keep well till the 6th week. Hence, it can be inferred that smoked catfish with moisture content of about $10 \%$ or less will have a shelf life of about 4 - 5 weeks under ambient storage conditions before the effect of spoilage microorganisms.
\end{abstract}

Index Terms - Catfish, smoke, Sango and Ota markets, microoganisms.

\section{INTRODUCTION}

Fish constitutes $40 \%$ of the animal protein intake of the people in Nigeria [1]. Consumption of fish and fish products is recommended due to good digestibility and the high content of polyunsaturated fatty acids [2]. Meanwhile, catfish is an important protein food in the tropics, it is widely reared, eaten cooked, roasted or smoked and sold in common markets.

However, Adesehinwa et al. [3] reported that captured fisheries which provides over $60 \%$ of total domestic production per annum, have been hampered largely due to post harvest losses; estimated at $30-50 \%$ of total catches. Fish is a highly perishable product due to its high susceptibility to autolysis, oxidation and hydrolysis of fats and microbial spoilage [4]. Chemical break down of protein, fat and water contents contribute to quick spoilage of fish. Also, the high ambient temperature in the tropics has been identified as a major cause of fish deterioration and there is need for immediate preservation as soon as fish is harvested

Published in April 26, 2020.

J.A. Daramola, Department of Biological Sciences, Bells University of

Technology, Nigeria.

(e-mail: john.a.daramola@gmail.com)

C. T. Kester, Department of Biological Sciences, Bells University of

Technology, Nigeria.

(e-mail: christieradeke@gmail.com)
[5]. The methods by which fish could be preserved include, freezing, salting, sun-drying, oven-drying, fermentation and smoking [6-7]. However, Bako [8], stated that smoking is the most popular method of fish processing in Nigeria. This is so as other methods of preservation are not adaptable in our local fishing areas and other techniques are expensive and rely on electricity or gas; that is not readily available. Hence, to achieve a delay or prevention of fish spoilage, preservative methods that include the use of smoke is inevitable so as to preserve the physical, chemical and nutritional qualities; enhance the economic value and prolong the shelf-life of smoked fish as a veritable protein source. The primary aim of smoking is to preserve the product, flavour and colour arising as a result of preservation function.

Ironically, Basti et al. [9] reported that processed fish are easily contaminated with microorganisms in nature, through handling, during processing and if the post-processing handling is not properly done under hygienic conditions. This is due to the fact that the curing method employed by local fish farmers is not standardised and most parameters like temperature, relative humidity, quality of smoke, smoke temperature remains uncontrolled which gives poor nutritional quality and high microbial loaded cured fish [10]. For example, Heintz and Johnson [11] revealed that smoked fish and shell fish products can be sources of microbial hazards including Listeria monocytogenes, Salmonella spp, and Clostridium botulinum.

Therefore, the broad objective is to study the changes in the microbiological qualities of smoked African catfish, Clarias gariepinus samples purchased from Ota and Sango markets stored under ambient conditions for a period of six weeks.

\section{MATERIALS AND METHOD}

\section{A. Sample Preparation and Analysis}

The fish samples used was purchased from Oja-Ota and Sango market, Ogun State. A preliminary investigation was made on the two markets. Six samples were purchased from each of the six retailers $(50 \%$ of the retailers), who were randomly picked; making a total of thirty-six (36) whole smoked fish samples for the experiment. It was gathered that the retailers purchased the stock of smoked fish from different places like Badagry, Idumota, and Ajilete. Samples of smoked fish were then transported in sterilised container

O. O. Allo, Department of Biological Sciences, Bells University of Technology, Nigeria.

(e-mail: allo.dahunsi@gmail.com) 
to the Bells University Research Laboratory for the weekly microbiological assessment.

The selected samples for the study were coded as follows:

SMR $1 \rightarrow$ Sango Market Retailer 1;

SMR 2 $\rightarrow$ Sango Market Retailer 2;

SMR $3 \rightarrow$ Sango Market Retailer 3;

OMR $1 \rightarrow$ Ota Market Retailer 1;

OMR $2 \rightarrow$ Ota Market Retailer 2;

OMR 3 $\rightarrow$ Ota Market Retailer 3 .

The Microbiological analyses carried out were Total Plate Count (TPC), Total Coliform Count (TCC), Staphylococcus and mould count.

Media/agar (Nutrient, MacConkey, Eosin Methylene Blue, Salmonella-shigella and Potato Dextrose) preparation were carried out following the standard methods. Thereafter, one gram of the catfish was separately weighed from the crushed or macerated fish portion and homogenised with $9 \mathrm{ml}$ of distilled water in a MacCartney bottle. Then, serial dilution of sample homogenates was prepared.

Incubation of culture plates was for 24 - 48 hours. Microbial counts and identification were carried out using standard procedure [12].

\section{B. Statistical Design and Data Presentation}

Completely Randomised Design (CRD) was adopted in carrying out this experiment. Mean values the microbial parameters were determined with standard deviation. The results were presented in tables.

\section{RESULTS AND DISCUSSION}

\section{A. Total Plate Count}

The TPC of the smoked fish samples increased with increasing period of storage (Table 1). Smoked catfish purchased from retailers at Sango market had a higher TPC count in week 0 and subsequent weeks compared to the ones from the retailers in Ota market. A continuous increase in TPC, from $4.75 \pm 0.014 \log _{10} \mathrm{CFU} / \mathrm{g}$ for smoked samples from Ota market, retailer $1(\mathrm{OMR} 1)$ in week 0 to $5.11 \pm 0.021$ $\log _{10} \mathrm{CFU} / \mathrm{g}$ for samples from Ota market, retailer 3 (OMR3) in week 5. Meanwhile, the range of specified microbiological limits recommended by International Commission for Microbiological Specification for Food [13] for bacterial count for good quality fish and fishery products is maximum $(\mathrm{m})$ of $5 \times 10^{5}(5.7 \log 10 \mathrm{CFU} / \mathrm{g})$ to for marginally acceptable level of $10^{7}$ ( 7 log $\left.10 \mathrm{CFU} / \mathrm{g}\right)$. Similarly, higher Total Plate Count (TPC) of $10^{6}$ per gram or above is considered to be of poor quality for fish [14]. The acceptable limit of bacterial count for dried fish is $1 \times 10^{5}$ at $37^{\circ} \mathrm{C}[15]$.

\section{B. Total Coliform Count}

The TCC of the two study markets- Sango and Ota during the six weeks of storage is presented in Table 2. There was a slight or marginal increase in the TCC of all the smoked fish sampled. The lowest value of TCC was recorded for smoked fish sample from Oja market, retailer 1 in week 0 at $1.47 \pm 0.001 \log _{10} \mathrm{CFU} / \mathrm{g}$ and highest been samples procured from Sango market, retailer 1 at $2.43 \pm 0.049 \log _{10} \mathrm{CFU} / \mathrm{g}$ in week 5. Akinwumi and Adegbehingbe [14] that carried out the microbiological analysis of three smoked fish samples, obtained from the Ondo State, Nigeria reported TCC range of $3 \times 10^{3} \mathrm{cfu} / \mathrm{ml}$ to $1.9 \times 10^{5} \mathrm{cfu} / \mathrm{ml}$.

\section{Staphylococcus Count}

There was increase in the Staphylococcus count of the smoked fish samples during the weeks of storage (Table 3). The least recorded Staphylococcus count was 2.15 \pm 0.070 $\log _{10}(\mathrm{CFU} / \mathrm{g})$ from Ota market, retailer 1 (OMR1) in week 0 while the highest count of $2.66 \pm 0.014 \log _{10}(\mathrm{CFU} / \mathrm{g})$ was observed for smoked catfish from Sango market, retailer 3 (SMR3) in week 5. Food may be contaminated during processing and handling. Varnam [16] reported Staphlococcus count of $2.7 \times 10^{2}-5.3 \times 10^{3}$. Meanwhile, ICMSF [15] reported Staphylococcus count of m value of $10^{3}$ (3 $\log 10 \mathrm{CFU} / \mathrm{g}$ ). In addition, Omojowo and Ihuahi [17] and Ibrahim et al. [18] also reported that smoked fish samples from four local markets in Minna and Kainji Lake area of Nigeria were dominated by gram-positive bacteria, potential pathogens, coagulase-positive Staphylococcus and Escherichia coli. Also, Abolagba et al. [19]; Abolagba and Uwagbai [20] and Martin [21] stated that bacteria such as Staphylococcus aureus, Proteus, Bacillus, Micrococcus, were the most common microorganism associated with smoked fish.

\section{Mould Count}

The mould count of all the samples purchased from the two markets increased consistently with the storage time (Table 4). Also, the rate of increase of the mould count was also observed to be similar for smoked catfish samples from both Sango and Ota markets. Mould count as low as $1.82 \pm 0.070$ $\log _{10}$ CFU/g was recorded in week 0 for fish samples from Sango market, retailer 2 (SMR2) while the highest count of $2.92 \pm 0.071 \log _{10} \mathrm{CFU} / \mathrm{g}$ was obtained in week 5 for sample from Sango market, retailer 3 (SMR3).

Though, Josephson et al. [22] stated that smoking process is effective in controlling the onset of fungal attack. Fungi are microorganisms that can grow rapidly during preservation or storage. The distribution of these mould (fungi) probably results from the ubiquitous nature of fungi in agreement with Ibeh et al. [23]. Their presence in the smoked catfish could be as a result of fungus acquisition from the retailers since it is acquired by contact with contaminated soil or with infected animals or humans [24]. Also, the absorption of atmospheric water vapour by the relatively dry smoked fish will increase the moisture content and make it more susceptible to mould growth. This agreed with Gibson et al. [25] findings that the composition of the atmosphere has a great impact on mould growth with humidity being the most important variable. 
TABLE I: MEAN TOTAL PLATE COUNT (TPC) FOR SMOKED Clarias gariepinus SAMPLES (Log10 CFU/g)

\begin{tabular}{lcccccc}
\hline MKTS & WEEK 0 & WEEK 1 & WEEK 2 & WEEK 3 & WEEK 4 \\
\hline SMR1 & $4.81 \pm 0.028$ & $4.87 \pm 0.021$ & $4.94 \pm 0.021$ & $4.94 \pm 0.028$ & $5.02 \pm 0.014$ & $5.08 \pm 0.014$ \\
SMR2 & $4.83 \pm 0.028$ & $4.91 \pm 0.014$ & $4.95 \pm 0.007$ & $4.97 \pm 0.040$ & $5.02 \pm 0.007$ \\
SMR3 & $4.78 \pm 0.035$ & $4.87 \pm 0.021$ & $4.91 \pm 0.021$ & $4.95 \pm 0.028$ & $4.98 \pm 0.014$ \\
OMR1 & $4.75 \pm 0.014$ & $4.83 \pm 0.028$ & $4.92 \pm 0.042$ & $4.93 \pm 0.021$ & $5.07 \pm 0.014$ \\
OMR2 & $4.81 \pm 0.148$ & $4.77 \pm 0.021$ & $4.85 \pm 0.028$ & $4.86 \pm 0.040$ & $4.98 \pm 0.035$ & $4.95 \pm 0.007$ \\
OMR3 & $4.81 \pm 0.028$ & $4.89 \pm 0.021$ & $4.98 \pm 0.014$ & $5.99 \pm 0.035$ & $5.01 \pm 0.035$ & $5.04 \pm 0.056$ \\
\hline
\end{tabular}

TABLE II: MEAN TOTAL COLIFORM COUNT FOR SMOKED Clarias gariepinus SAMPLES (Log ${ }_{10}$ CFU/g)

\begin{tabular}{lrrrrr}
\hline MKTS & WEEK 0 & WEEK 1 & WEEK 2 & WEEK 3 & WEEK 4 \\
\hline SMR1 & $1.90 \pm 0.077$ & $2.00 \pm 0.756$ & $2.10 \pm 0.056$ & $2.19 \pm 0.070$ & $2.21 \pm 0.643$ \\
SMR2 & $1.83 \pm 0.000$ & $1.85 \pm 1.166$ & $1.92 \pm 0.077$ & $1.95 \pm 0.091$ & $1.99 \pm 0.919$ \\
SMR3 & $1.75 \pm 0.919$ & $1.82 \pm 0.388$ & $1.90 \pm 0.424$ & $1.96 \pm 0.848$ & $2.10 \pm 0.282$ \\
OMR1 & $1.47 \pm 0.001$ & $1.58 \pm 0.304$ & $1.67 \pm 0.098$ & $1.74 \pm 0.042$ & $1.79 \pm 0.197$ \\
OMR2 & $1.52 \pm 0.424$ & $1.56 \pm 0.707$ & $1.69 \pm 0.141$ & $1.72 \pm 0.452$ & $1.86 \pm 0.551$ \\
OMR3 & $1.48 \pm 0.000$ & $1.49 \pm 0.671$ & $1.52 \pm 0.113$ & $1.69 \pm 0.148$ & $1.94 \pm 0.063$ \\
\hline
\end{tabular}

TABLE III: MEAN STAPHYLOCOCCUS COUNT FOR SMOKED Clarias gariepinus SAMPLES (Log ${ }_{10}$ CFU/g)

\begin{tabular}{|c|c|c|c|c|c|c|}
\hline MKTS & WEEK 0 & WEEK 1 & WEEK 2 & WEEK 3 & WEEK 4 & WEEK 5 \\
\hline SMR1 & $2.30 \pm 0.021$ & $2.38 \pm 0.035$ & $2.47 \pm 0.014$ & $2.56 \pm 0.014$ & $2.61 \pm 0.014$ & $2.65 \pm 0.021$ \\
\hline SMR2 & $2.20 \pm 0.141$ & $2.30 \pm 0.077$ & $2.39 \pm 0.021$ & $2.53 \pm 0.028$ & $2.59 \pm 0.028$ & $2.63 \pm 0.021$ \\
\hline SMR3 & $2.32 \pm 0.120$ & $2.42 \pm 0.035$ & $2.50 \pm 0.000$ & $2.52 \pm 0.014$ & $2.60 \pm 0.007$ & $2.66 \pm 0.014$ \\
\hline OMR1 & $2.15 \pm 0.070$ & $2.26 \pm 0.035$ & $2.39 \pm 0.042$ & $2.47 \pm 0.035$ & $2.53 \pm 0.028$ & $2.60 \pm 0.021$ \\
\hline OMR2 & $2.16 \pm 0.035$ & $2.26 \pm 0.049$ & $2.36 \pm 0.028$ & $2.42 \pm 0.021$ & $2.51 \pm 0.028$ & $2.59 \pm 0.042$ \\
\hline OMR3 & $2.22 \pm 0.042$ & $2.32 \pm 0.021$ & $2.39 \pm 0.021$ & $2.49 \pm 0.007$ & $2.54 \pm 0.021$ & $2.60 \pm 0.042$ \\
\hline
\end{tabular}

TABLE IV: MEAN MOULD COUNT FOR SMOKED Clarias gariepinus SAMPLES ( $\log _{10}$ CFU/g)

\begin{tabular}{cccccc}
\hline MKTS & WEEK 0 & WEEK 1 & WEEK 2 & WEEK 3 & WEEK 5 \\
\hline SMR1 & $2.02 \pm 0.106$ & $2.05 \pm 0.070$ & $2.18 \pm 0.035$ & $2.21 \pm 0.028$ & $2.30 \pm 0.014$ \\
SMR2 & $1.82 \pm 0.070$ & $2.18 \pm 0.035$ & $2.18 \pm 0.120$ & $2.19 \pm 0.077$ & $2.37 \pm 0.049$ \\
SMR3 & $2.20 \pm 0.042$ & $2.20 \pm 0.049$ & $2.21 \pm 0.148$ & $2.40 \pm 0.035$ & $2.46 \pm 0.176$ \\
OMR1 & $2.02 \pm 0.106$ & $2.18 \pm 0.028$ & $2.21 \pm 0.155$ & $2.23 \pm 0.028$ & 2.028 \\
OMR2 & $1.95 \pm 0.070$ & $2.21 \pm 0.035$ & $2.23 \pm 0.042$ & $2.36 \pm 0.007$ & $2.40 \pm 0.049$ \\
OMR3 & $2.02 \pm 0.106$ & $2.25 \pm 0.028$ & $2.27 \pm 0.049$ & $2.31 \pm 0.169$ & $2.49 \pm 0.49$ \\
\hline
\end{tabular}


Generally, the poor sanitary conditions at the levels of our local markets, fish handlers and fish smoking facilities may contribute to the presence of microorganisms in smoked fish [26]. Persistence of these have led to food poisoning with alarming health problems in developing countries where sanitation is low [27]. The higher microbial counts on fish from some of the markets may be likely due to a lack of proper smoking on the side of the fish processors, improper hygienic and handling procedures adopted by the smoked fish sellers [19].

In addition, if not properly stored, the efforts involved in smoking would not yield the expected preservative effect [28]. Meanwhile, brining e.g. treatments with 20 and $25 \%$ salt have proved best in terms of microbial reduction of the TVC, Coliform, Staphylococcus and fungi after smoking with the low microbial counts maintained for eight (8) weeks of storage [29].

\section{CONCLUSION AND RECOMMENDATION}

If the percentage moisture of freshly smoked Clarias gariepinus is much, microbial activity and biodeterioration will be very high. Therefore, a properly smoked Clarias gariepinus with moisture content of about $10 \%$ or less will have a shelf life of about $4-5$ weeks under appropriate storage condition; capable of preventing the growth of spoilage microorganisms.

\section{REFERENCES}

[1] Olatunde, A. A. Approaches to the study of fisheries biology in Nigerian inland waters. Proc. nat. con. of two decades of research on lake kainji. Ayeni and Olatunde (eds). pp. 1538-1541, 1989.

[2] Ayeloja, A. A, George, F. O. A, Jimoh, W. A, Shittu, M. O, and Abdulsalami, S. A. Microbial load on smoked fish commonly traded in Ibadan, Oyo State. Nigeria. J. Appl. Sci. Environ. Manage, vol. 22, no. 4, pp. 493-497, 2018.

[3] Adesehinwa, A. O. K, Ayanda, J. O, and Bolorunduro, P. I. Adoption of improved fish preservation technologies in Northwestern Nigeria. Tropicultural, vol. 23, pp. 117-123, 2005.

[4] Olaleye, O. N, and Abegunde, T. A. Microbiological safety assessment of selected smoked fish in Lagos metropolis. British Microbiology Research Journal, vol. 9, no. 3, pp. 1-5, 2015

[5] Aberoumand, A. Estimation of microbiological variations in minced lean fish products. World J. Fish and Marine Sci., vol. 2, no. 3, pp. 204-207, 2010.

[6] Clucas, I. J, and Ward, I. J. Post-harvest fisheries development: a guide to handling/preservation, processing and quality. Natural Resource Institute Chatham Meantime, Kent, United Kingdom, pp. 443, 1996.

[7] Asiedu, M, and Sanni, A. I. Chemical composition and microbiological changes during spontaneous and starter culture fermentation of Enam Ne-Setaakye, a West African fermented fishcarbohydrate product. Euro. Food Res. Tech., vol. 215, no. 1, pp. 8$12,2002$.

[8] Bako, W. S. The role of women in fish processing: Handling and marketing in Kainji Lake basin. Proceedings of 19th Annual Conference of the Fisheries Society of Nigeria (FISON), Nov.29Dec.3, 2004, Ilorin, Nigeria, 2005.

[9] Basti, A. A, Misaghi, A, Salehi, T. Z, and Kamkar, A. Bacterial pathogens in fresh, smoked and salted Iranian fish. Food Control, vol. 17, pp. 183-188, 2006.

[10] Jakhar, J. K, Anirudh Kumar, A, and Vardia, H. K. Hygenicity and nutritional quality of traditional dried and smoked fishes at kawardha fish market, (Chhattisgarh), India. The Bioscan, vol. 10, no. 3, pp. 1099-1102, 2015.

[11] Heintz, M. L, and Johnson, J. M. The Incidence of Listeria spp., Salmonella spp. and Clostridium botulinum in smoked fish and shellfish. Journal of Food Protection, vol. 61, no. 3, 318-323, 1998.
[12] Fawole, M. O, and Osho, B. A. Laboratory manual of microbiology. Shalom prints Ibadan, Nigeria. pp. 25-30, 1995

[13] International Commission on Microbiological Specifications for Foods-(ICMSF). Microorganisms in Foods 2, sampling for microbiological analysis. Principles and Specific Applications, 2nd edn. Oxford: Blackwell Science, 1986.

[14] Akinwumi, F. O, and Adegbehingbe, K. T. Microbiological analysis of three of smoked fish obtained from the Ondo State, Nigeria. Food and Public Health, vol. 5, no. 4, pp. 122-126, 2015.

[15] Surendran, P, Nirmala, Thampuran, K, Narayanannambiar, V, and Lalitha, K. V. Manual on microbiological examination of seafood. Laboratory M, and Mathew, P. T. (Eds), CIFT and SOFT, Cochin, 2nd edn. pp. 28-45, 2006.

[16] Varnam, A. H. Foodborne pathogens: an illustrated text. Mosby- Year Book, Inc., London, 1991.

[17] Omojowo, F. S, and Ihuahi, J. A. Microbiological quality and safety of smoked fish from kainji lake area. African Scientist, vol. 7, no. 4, 2006.

[18] Ibrahim, B. U, Baba, J, and Sheshi, M. S. Isolation and identification of bacteria associated with fresh and smoked fish (Clarias gariepinus) in Minna Metropolis, Niger State. Nigeria. Journal of Applied and Environmental Microbiology, vol. 2, no. 3, pp. 81-85, 2014.

[19] Abolagba, O. J, Adekunle, A. T, Dede, A. P. O, and Omoigui, G. O. Microbial assessment of smoked fish (Clarias spp) in Benin Metropolis, Edo State, Nigeria. Nigerian Journal of Agriculture, Food and Environment, vol. 7 no. 3, pp. 55-58, 2011.

[20] Abolagba, O. J, and Uwagbai, E. C. A. Comparative analysis of the microbial load of smoke dried fishes (Ethmalosa fimbriata and Pseudolithus elongatus) sold in Oba and Koko markets in Edo and Delta States, Nigeria at different seasons. Australian Journal of Basic and Applied Sciences, vol. 5, no. 5, pp. 544-550, 2011.

[21] Martin, A. M. Fisheries processing biochemical applications. Chapman and Hall Publisher, London, 1994.

[22] Josephson, D. B, Lindsay, R. C, and Stuiber, D. A. Influence of processing on the volatile compounds characterizing the flavor of pickled fish. Journal of Food Science, vol. 52, no. 1, pp. 10-14, 1987.

[23] Ibeh, I. N, Uriah, N, Ogonor, J. I. Dietary exposure to aflatoxin in Benin city, Nigeria: a possible public health concern. Int. J. Food Microbiol. Vol. 14, pp. 171-174, 1991.

[24] Mitchell T. G. Medical Mycology In: Jawetz, Melnick and Adelberg's (eds). Medical Microbiology 24th Edition. McGraw Hill USA. pp. 621-625, 2007.

[25] Gibson, A. M, Baranyi, J, Pitt, M. J, Eyles, M. J, and Roberts, T. A. Predicting fungal growth: The effect of water activity on Aspergillus flavus and related species. Int. J. Food Microbial. Vol. 23, pp. 419431, 1994.

[26] Ibanga, I. J, Moses, E. A, Edet, E. J, and Moses, A. E. Microbial and some heavy metals analysis of smoked fishes sold in urban and rural markets in Akwa Ibom State, Nigeria. Calabar J. Health Sci 3(2):7379,2020

[27] Olayemi, F.F., Raji, A.O. and Adedayo, M.R. Microbiological quality of catfish (Clarias gariepinus) smoked with Nigerian Stored Products Research Institute (NSPRI) developed smoking kiln. Int. Res. J. Microbiol. Vol. 3, pp. 426-430, 2012.

[28] Daramola, J. A, Fasakin, E. A, and Adeparusi, E. O. Changes in physicochemical and sensory characteristics of smoke-dried fish species stored at ambient temperature. African Journal of Food Agriculture Nutrition and Development, vol. 7, no. 6, pp. 157-160, 2007.

[29] Omojowo, F. S, Omojasola, P. F, Kolawole, M. O, Ngwu, E. O, Oluborode, G. B, Adetunji, C. O. Effect of brining on the microbial quality and safety of smoked catfish. New York Science Journal, vol. 3 , no. $6,2010$.

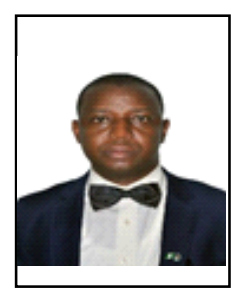

Dr. John A. Daramola, is presently a Senior Lecturer in Fisheries and Aquaculture Unit of Department of Biological Sciences, College of Natural and Applied Sciences, Bells University of Technology, Ota, Ogun State, Nigeria. Though, specialises in fish post-harvest technology (and animal biology), he has published in the area of fish culture, nutrition, fish processing and microbiology. He attended Federal University of Technology, Akure, Nigeria where he obtained his B.Agric.Tech.; Fisheries and Wildlife; M.Agric.Tech.; Fisheries Technology, and Ph.D., Fish Processing and Utilisation. He is a reviewer to some referred academic journals and has membership in professional 
bodies, including Fisheries Society of Nigeria (FISON), American Fisheries Society (AFS), and American Society for Microbiology (ASM). Department of Biological Sciences, Bells University of Technology, P.M.B. 1015 Ota. E-mail address: john.a.daramola@gmail.com 